\title{
Spatial distribution of physical attributes of an Ultisol under papaya crop
}

Julião Soares de Souza Lima', Walas Permanhane Sturião², Ivoney Gontijo³, Samuel de Assis Silva'

\author{
Universidade Federal do Espírito Santo, Alegre, ES, Brasil \\ 2Universidade Federal de Viçosa, Viçosa, MG, Brasil \\ *Corresponding author, e-mail: limajss@yahoo.com.br
}

\begin{abstract}
The successful development of the root system of plants depends on the favorable conditions of soil physical attributes. The objective of this work was to study the spatial variability of physical attributes in an Ultisol cultivated with papaya. The soil was prepared mechanically plowing, harrowing, sulcal and subsoiler. In the center of the crop field was built a sampling grid with points spaced $5.7 \mathrm{~m}$, totalizandol29 georeferenced points. The soil samples at two depths $(0$ $-0.20 \mathrm{~m}, 0.20-0.40 \mathrm{~m}$ ) were collected for four months after transplantation, to determine the total porosity (TP), soil moisture (Um), soil bulk density (BD) and soil penetration resistance in the planting row (PRPR) and in the traffic machines rows (PRROW). The soil penetration resistance in the planting row and in the traffic machines row was determined. The $B D_{1}$ and $B D_{2}$ showed the lowest CV values, and the data were fitted to the exponential and spherical models, respectively, with spatial dependence ranges of 20 and $28 \mathrm{~m}$. At the layer of 0-0.20 m depth, the attributes showed the same spatial distribution pattern. At the layer of 0-0.20 m depth, the soil penetration resistance showed 7.5 times greater in the traffic machines region (rw spacing) than the value found in the planting row.
\end{abstract}

Keywords: geostatistic, soil bulk density, spatial variability

\section{Introduction}

Among the activities carried out in the cultivation of papaya, in the Coastal Plains soils conventional soil tillage is widely applied, inverting the soil in the whole area in order to plant the seedlings. In the crop management, there is an intense traffic of machines in the row spacing, as well as during the harvesting. According to Pacheco \& Cantalice (2011), in this type of soil when subjected to excessive pressures and under certain soil moisture conditions the physical degradation process is favored.

Lima etal. (2012) mention that the Coastal Plains soils show low fertility and commonly has cohesive horizons, which hinder soil water dynamics, and then show low distribution and development of the plant root system.

The reduction of soil pores occurs with the traffic of machines due to the pressures applied by the wheels and consequently increases soil penetration resistance (PR). According to Silveira et al. (2010), PR is an adequate attribute to characterize the degree of soil compaction and makes possible to establish relations with the dynamics of growth and development of the root system of the plants.

Studies with soil physical attributes have shown the presence of continuity or spatial dependence, which is related to the management adopted and the soil parent 
material (Souza et al., 2009). Lima et al. (2007) state that the knowledge of the spatial variability of soil physical and chemical attributes is fundamental in order to minimize sampling errors and to optimize soil management. According to Gomes et al. (2007) and Campos et al. (2012), modeling the spatial dependence structure of soil attributes and variables related to plants, using geostatistics techniques, has been performed to understand their distributions in a given area as well as correlating them spatially with crop yields.

The characterization of the spatial variability of soil attributes associated with other decision-making techniques and the farmer's experience is important for the refinement of agricultural management practices and the evaluation of the effects of agriculture on environmental quality. Lima et al. (2009) verified that the total porosity (TP) and the soil bulk density (BD) showed the same pattern of spatial distribution in an area under pasture. According to Timm et al. (2006), soil moisture can influence the soil-plant relationship, water movement, soil aeration and root development.

Therefore, it is important that the papaya production system is the subject of advanced and applicable studies so that the papaya fields may be economical, environmentally and socially sustainable. The objective of this work was to study the spatial variability of soil penetration resistance, gravimetric water content, soil bulk density and total porosity of a cohesive dystrophic Argissolo Vermelho (typical - PAdx) or Ultisol (American Classification Soil Taxonomy) in the cultivation of papaya (Carica papaya L.).

\section{Materials and Methods}

The study was carried out in a papaya (Carica papaya L.) commercial field, variety Golden THB, Solo group, São Mateus county, in the northern of Espírito Santo state.

The climate of the region, according to the classification of Köppen, is Aw type, with a dry winter and hot and rainy summer. The climatic data was based on a historical series of the last 35 years showing an average annual temperature of $25,0^{\circ} \mathrm{C}$, the coldest month of $19,8^{\circ} \mathrm{C}$ and the hottest month of $29,8^{\circ} \mathrm{C}$, and accumulated average annual rainfall of $1,290 \mathrm{~mm}$.
The soil in the area is a typical cohesive dystrophic "Argissolo Vermelho" (PAdx) or Ultisol (American Classification Soil Taxonomy) of lowactivity clay. The area has a slightly hilly relief, a slope of approximately $3.0 \%$, typical of the Coastal Plains region at an altitude of $40 \mathrm{~m}$.

The soil granulometric fractions, in $\mathrm{kg}$ $\mathrm{kg}^{-1}$, at the layer of 0-0.20 m depth showed the following values: total sand content $=891.8$; silt content $=15.6$ and clay content $=92.6$ and at the layer of $0.20-0.40 \mathrm{~m}$ depth total sand content $=$ 873.6; Silt content $=16.7$ and clay content $=109.7$.

The study area was fallow and occupied with typical "dirty field" vegetation (Capoeira) for a period of six years. The soil tillage in the area was carried out at 40 days before planting the seedlings, the Capoeira vegetation was removed by a rotary cutter, afterward, the vegetable wastes were piled and burned. In the soil tillage, a ballast tractor was used coupled to a fixed 3-disc 26" plow mounted, performing the operation at the layer of 0-20 m depth. Soil harrowing, with two passes, was performed with a disk harrow with four bodies (in tandem) and 24 discs with 20 ", working at a depth of approximately $0.15 \mathrm{~m}$.

Mechanized furrow operation was performed at $0.20 \mathrm{~m}$ depth, according to the spacing used: $3.3 \times 2.0 \times 1.90$, in double rows $\left(1986 \mathrm{ha}^{-1}\right)$. After fertilization, a tubular chassis plow levee was used inside the furrows at 0.50 $\mathrm{cm}$ depth in order to homogenize the fertilization as well as to break the compacted sub surface layers of the soil, and then, planting the seedlings.

A regular grid with 129 sample points, $110 \times 114 \mathrm{~m}$, was designed at the center of the crop field with adjacent points spaced at $5.7 \mathrm{~m}$, $10.6 \mathrm{~m}$ and $21.2 \mathrm{~m}$, totaling 129 georeferenced points (Figure 1).

Undisturbed soil samples were collected at the 129 sampling points, in the canopy region of papaya plants using an auger. Samples were collected in the direction of the planting row at two $0.20-\mathrm{m}$ equidistant points, at the layer of $0-0,20 \mathrm{~m}$ (1) and 0,20-0,40 m (2) depth, four months after planting (identification of sex).

The samples were placed in plastic bags and homogenized. A soil subsample was collected per point and sealed in a proper container. Soil gravimetric water content (U) and 
soil bulk density (BD) were determined by the test-tube method (Embrapa, 2011). Total porosity (TP) was estimated by the following equation: TP (m3 m-3) = [(PD-BD) / PD], where PD is soil particle density.

Soil penetration resistance (PR) was measured and recorded using a field penetrometer equipped with a conical tip in a vertex angle of $30.0^{\circ}$, allowing data acquisition every $1.0 \mathrm{~mm}$ until $0.40 \mathrm{~m}$ depth. A sampling point reading was performed in the canopy region on the planting row (PRPR) at 0,20 m from the plant stem, at the same time when the soil sampling was collected. Therefore, the measurement of PRPR was performed in the rhizosphere region.

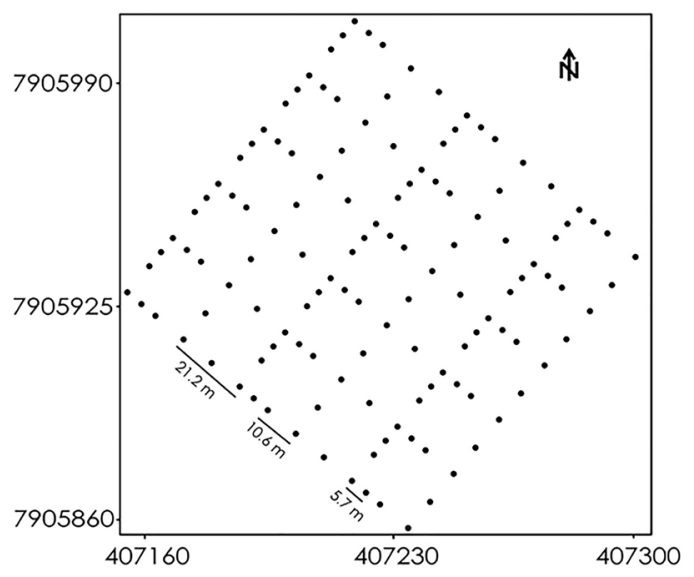

Figure 1. Sample grid design.

It was also performed the measurement of the PR in the rows of the machines traffic (Row spacing - PRRow), perpendicularly to the measurement performed in the planting row, according to the methodology used by Lima et al. (2008). The PRRow was analyzed in order to study the additional incremental in the soil resistance provided by the traffic of machines in the orchard row spacing. The average values of PR were obtained at the layers of $0-0.20$ and 0.20-0.40 m depth, for the planting row condition (PRPR) and the traffic of machines condition (RPROW).

Soil penetration resistence was classified as established by Arshad et al. (1996): a) extremely low: PR <0.01 MPa; B) very low: $0.01 \leq P R<0.1$ MPa; C) low: $0.1 \leq P R<1.0 \mathrm{MPa}$; D) moderate: 1.0 $\leq P R<2.0 \mathrm{MPa}$; E) high: $2.0 \leq \mathrm{PR}<4.0 \mathrm{MPa}$; F) very high: $4.0 \leq \mathrm{PR}<8.0 \mathrm{MPa}$; and $\mathrm{g}$ ) extremely high: $\mathrm{PR}>8.0 \mathrm{MPa}$.

In the exploratory analysis of the data and in the outliers study boxplot was used, which considers the interquartile relationship. Once identified, they were removed in the data set, being: 2 in the $\mathrm{BD}_{2}, 3$ in the UPR, 4 in the $\mathrm{UPR}_{2}, 6$ in the URow, and the URow ${ }_{2}$. After this procedure, descriptive statistical analyses were performed to define position and dispersion measurements, as well as the Kolmogorov-Smirnov (KS) normality test ( $p<0.05$ ). Pearson's correlation analysis was performed ( $p<0.05$ ), adopting the classification proposed by Kitamura et al. (2007).

Geostatistical analysis was used to verify and quantify the degree of spatial dependence of the attributes at the two layers, which was performed fitting theoretical functions to the experimental semivariogram models, based on the assumption of intrinsic stationarity according to equation 1.

$$
\gamma^{*}(h)=\frac{1}{2 N(h)} \sum_{i=1}^{N(h)}\left[z\left(x_{i}\right)-z\left(x_{i}+h\right)\right]^{2}
$$

where: $N(h)=$ is the number of experimental paired of observations $Z\left(x_{i}\right), z\left(x_{i}+h\right)$, separated by a lag $h$.

The trend analysis was performed with the $x$ and $y$ axes for all attributes, as described in Lima et al. (2010), however, significant correlations were not observed.

The semivariogram parameters which are nugget effect $(\mathrm{CO})$, sill $(\mathrm{CO}+\mathrm{C})$ and the spatial dependence range (a) were determined for all studied variables. Cross-validation results were 
used to determine the best model, observing the correlation between the predicted value and the measured values at each sampling point. In order to determine the spatial dependence degree (SDD), the following equation was used $[\mathrm{CO} /(\mathrm{CO}+\mathrm{C} 1)]^{*} 100$ according to the criteria established by Cambardella et al. (1994) which considers the strong spatial dependence semivariograms having nugget effect equal to $25 \%$ of the sill; moderate spatial dependence when the nugget effect is between 25 and $75 \%$ and low spatial dependence when the nugget effect is greater than $75 \%$.
The semivariograms were standardized by the data variance to make easy the interpretation of the attributes in the different conditions, as well as to observe the presence of the same spatial variability pattern since the semivariograms show values on a standardized scale.

When the spatial dependence of the attributes was confirmed and the theoretical semivariograms defined, ordinary kriging interpolation was performed to estimate values at unmeasured locations in order to construct thematic maps for each attribute.

Table 1. Descriptive analysis of soil bulk density (BD), total porosity (TP), soil water gravimetric content (U) and soil penetration resistance (PR)

\begin{tabular}{|c|c|c|c|c|c|c|c|c|c|c|c|c|c|}
\hline Attribute & $\mathrm{N}$ & mean & Md & $S$ & Min. & Max. & $\mathrm{CV}$ & Q1 & Q3 & $\mathrm{Ca}$ & IR/TR(\%) & Ck & ND \\
\hline $\mathrm{BD}_{1}\left(\mathrm{~kg} \mathrm{dm^{-3 }}\right)$ & 129 & 1,5 & 1,5 & 0,07 & 1,3 & 1,6 & 4,6 & 1,4 & 1,5 & $-0,17$ & 33,3 & $-0,11$ & $\mathrm{~ns}$ \\
\hline $\mathrm{BD}_{2}\left(\mathrm{~kg} \mathrm{dm}{ }^{-3}\right)$ & 127 & 1,4 & 1,5 & 0,1 & 1,3 & 1,5 & 3,6 & 1,4 & 1,5 & $-0,17$ & 50,0 & $-0,43$ & ns \\
\hline $\mathrm{PRPR}_{1}(\mathrm{MPa})$ & 129 & 0,2 & 0,2 & 0,2 & 0,0 & 0,9 & 72,4 & 0,1 & 0,3 & 1,74 & 22,2 & 3,24 & $*$ \\
\hline $\mathrm{PRPR}_{2}(\mathrm{MPa})$ & 129 & 1,0 & 0,9 & 0,7 & 0,1 & 3,1 & 66,8 & 0,5 & 1,5 & 0,47 & 33,3 & $-0,50$ & ns \\
\hline$U P R_{1}(\%)$ & 126 & 7,4 & 7,4 & 1,5 & 3,8 & 11,1 & 19,8 & 6,5 & 8,2 & 0,08 & 23,3 & 0,13 & ns \\
\hline $\mathrm{UPR}_{2}(\%)$ & 125 & 6,9 & 6,5 & 1,8 & 3,3 & 11,8 & 25,8 & 5,8 & 7,7 & 4,50 & 22,4 & 0,81 & $*$ \\
\hline PRROW $_{1}(\mathrm{MPa})$ & 129 & 1,5 & 1,5 & 0,2 & 0,9 & 2,1 & 15,1 & 1,3 & 1,6 & 0,52 & 25,0 & 0,39 & ns \\
\hline $\mathrm{PRROW}_{2}(\mathrm{MPa})$ & 129 & 2,0 & 2,0 & 0,4 & 0,6 & 3,0 & 20,0 & 1,8 & 2,3 & $-0,32$ & 20,8 & 1,23 & $\mathrm{~ns}$ \\
\hline URow $_{1}(\%)$ & 123 & 8,3 & 7,6 & 2,3 & 4,1 & 17,5 & 27,4 & 7,0 & 8,7 & 1,95 & 12,7 & 5,10 & $*$ \\
\hline URow $_{2}(\%)$ & 123 & 7,8 & 7,5 & 1,7 & 3,0 & 13,0 & 22,0 & 6,7 & 9,1 & 0,42 & 24,0 & 0,69 & ns \\
\hline $\mathrm{TP}_{1}\left(\mathrm{~m}^{3} \mathrm{~m}^{-3}\right)$ & 129 & 0,50 & 50,9 & 3,7 & 38,5 & 58,3 & 7,4 & 47,7 & 52,8 & $-0,61$ & 25,8 & 0,25 & $\mathrm{~ns}$ \\
\hline $\mathrm{TP}_{2}\left(\mathrm{~m}^{3} \mathrm{~m}^{-3}\right)$ & 129 & 0,50 & 50,4 & 3,0 & 42,7 & 58,4 & 6,0 & 47,6 & 52,0 & 0,0 & 28,0 & $-0,26$ & $\mathrm{~ns}$ \\
\hline
\end{tabular}

\section{Results and Discussion}

Measures of central tendency such as the mean and median of all attributes at the layers of $0-0.20 \mathrm{~m}$ (1) and $0.20-0.40 \mathrm{~m}$ (2) depth are shown in Table 1.

The attributes that showed $\mathrm{Ca}$ and $\mathrm{Ck}$ values close to zero, the data normal distribution was confirmed by the KS test ( $p<0.05)$, moreover the mean and median (Md) values showed similar values. In the geostatistical analysis, it is desirable that the data distribution does not have very long tails, which was eliminated in this present study removing outliers (Isaaks \& Srivastava, 1989)

Positive asymmetry ( $\mathrm{Ca}$ ) was found in $67.7 \%$ of the attributes, showing the mean value greater or equal to the median value, indicating a concentration of data with values greater than the mean value. Positive kurtosis coefficient (Ck) was found in $67.7 \%$ of the data (leptokurtic), with the data concentrated around the mean.

Based on the $\mathrm{CV}$ values according to the classification proposed by Warrick \& Nielsen (1980), $\mathrm{BD}_{12}$ and $\mathrm{TP}_{12}$ (layer 1 and 2) showed low variability $(\mathrm{CV}<12.0 \%)$; $\mathrm{UPR}_{12}$, PRROW $_{12}$ and UROW $_{12}$ showed moderate variability $(12.0 \% \leq \mathrm{CV}$ $\leq 60.0 \%$ ), and $\mathrm{PRPR}_{12}$ showed high variability. CV values lower than $12.0 \%$ for $\mathrm{BD}_{1}$ and $\mathrm{TP}_{1}$ were found by Lima et al. (2007) in a "Latossolo Vermelho Amarelo" (Oxisol) cultivated with black pepper in northern Espírito Santo state and by Lima et al. (2009) in an "Argissolo" (Ultisol) cultivated with pasture and regenerating natural vegetation, in the south of Espírito Santo state. Lima et al. (2008) stated that the CV values for PR decreases as increasing soil compaction, as confirmed for the PR on the traffic of machines region (row spacing). Dalchiavon et al. (2011) found for the RP values in Cerrado (Brazilian native vegetation) 
soil, "Latossolo Vermelho Distroférrico" (Oxisol), CV values of $38.0 \%$ and $22.0 \%$, respectively, for the layer of 0-0.10 m and 0.10-0.20 m depth.

The variable $\mathrm{BD}_{2}$ showed $\mathrm{IR}$ value $=0.10$ and $T R$ value $=0.20$, thus the ratio was $50.0 \%$, indicating a large concentration of the values around the mean. This result demonstrated that the effect of extreme values was not evident, which led to the lowest CV among the studied attributes.

The mechanized operations in the area and the higher soil moisture (U) provided lower PR values at the layer of $0-0.20 \mathrm{~m}$ depth (0.20 MPa) than at the layer of $0.20-0.40 \mathrm{~m}$ depth (1.0 MPa ). This fact occurs also due to the textural gradient found in "Argissolos" (Ultisol).

The PR at the layer of 0-0.20 m depth was classified as low $(0.1 \leq P R<1.0)$ whereas at the layer of 0.20-0.40 $\mathrm{m}$ was moderate (1.0 $\leq \mathrm{PR}<2.0$ ). According to Arshad et al. (1996), the average PR values found at the two soil layers, in the planting row is not indicating a restriction to the penetration limiting to the papaya root growth, since the restrictive value is higher than 2.0 MPa. However, Andrade et al. (2013) stated that penetration resistance in Cerrado soils showing values equal to or greater than $1.90 \mathrm{MPa}$ can be considered as a compacted soil indicator when soil moisture is within the range of 6.2 to $9.6 \%$.

The soil bulk density (BD) and total porosity (TP) at the two layers in the planting row were 1.50 and $1.40 \mathrm{~kg} \mathrm{dm}^{-3}$ and $0.50 \mathrm{~m}^{3} \mathrm{~m}^{-3}$, respectively. The $\mathrm{BD}$ and $\mathrm{TP}$ mean values are close to $1.45 \mathrm{~kg} \mathrm{dm}^{-3}$ and $0.45 \mathrm{~m}^{3} \mathrm{~m}^{-3}$, respectively, as found by Lima et al. (2007) in a "Latossolo Vermelho Amarelo Distrófico" (Oxisol) with 638.5 $\mathrm{g} \mathrm{kg}^{-1}$ of coarse sand (CS) (0-0.20 m) cultivated with black pepper in northern Espírito Santo state. Pires et al (2011) state that BD can be used as an indicator of the degree of soil compaction since it is a porous material and by compression, the same mass can occupy a smaller volume.

PR and soil moistere (U) were the only attributes performed in the tire traffic row, PRRow and URow, respectively, to identify and compare the effect of the machine traffic to the papaya root development region (planting row). It was verified higher mean value for PRRow ${ }_{2}$ (0.20-0.40 $\mathrm{m}$ depth). This result is due to the soil preparation occurred only in the topsoil and due to the intrinsic characteristics of this soil, since the soil moisture (U) showed similar values between the layers. The PRRow, at the layer of 0-0.20 m depth (1.5 MPa) was classified as moderate (1.0 $\leq$ PR $<2.0$ ) whereas the PRRow ${ }_{2}$ at the layer of 0.20-040 $m$ depth $(2.0 \mathrm{MPa})$ as high $(2.0 \leq \mathrm{PR}<4.0)$.

Thus, it is identified that the compacting process in the machine traffic region, the RPRow was seven and a half times higher at the layer of 0-0.20 m depth compared to PRPR. While at the layer of 0,20-0,40 $\mathrm{m}$ depth in the machine traffic region (PRRow), the RP was twice higher than in the planting row (PRPR).

Silveira et al. (2010) studying the PR in relation to the soil moisture (U) of an "Argissolo Amarelo distrocoeso" (Ultisol) in northeastern Bahia state, verified that the $U$ changes the cohesion between the soil particles. Thus, when the soil shows low soil moisture, its particles are closer and shows higher PR for any applied external force. Lima et al. (2005) evaluating the physical attributes of an "Argissolo Acizentado distrófico arênico coeso" (Ultisol), typical in the Coastal Plains, in Ceará state, observed BD of $1.75 \mathrm{~kg} \mathrm{dm}^{-3}$ and considered this to be the main cause of natural occurrence of the cohesive $\mathrm{B} \dagger$ horizon, showing low TP values and PR of 3.0 MPa. The authors reaffirmed the positive correlation of the cohesion phenomenon with the fine fractions of the soil (silt and clay).

Kitamura et al. (2007) correlation classification was adopted for the Pearson correlation analysis $(p<0.05)$. The correlations found were: high $(0,6 \leq r<0,8)$ for $\operatorname{TP}_{1} \times \mathrm{BD}_{1}(r=$ $-0,71)$ and $\operatorname{UPR}_{2} \mathrm{XUROW}_{2}(r=0,68)$; moderate $(0,4$ $\leq r<0,6)$ for $\mathrm{BD}_{2} \times \mathrm{UPR}_{2}(r=-0,42), \mathrm{BD}_{1} \times \mathrm{XUROW}_{1}(r=$ $-0,44), \mathrm{BD}_{2} \times \mathrm{UROW}_{2}(r=-0,43), \mathrm{BD}_{2} \times \mathrm{TP}_{2}(r=-0,40)$ and UROW ${ }_{2} \times$ PRROW $_{2}(r=0,40)$; IOW $(0,2 \leq r<0,4)$ for $\mathrm{BD}_{1} \times \mathrm{XUPR}_{1}(r=-0,30), \mathrm{PRPR}_{1} \mathrm{XPRROW}_{1}(r=0,32)$, $\mathrm{BD}_{2} \times \mathrm{XPPR}_{2}(r=-0,30)$ and $U P R_{1} \times \mathrm{XURW}_{1}(r=0,29)$.

The negative correlation between $\mathrm{BD}$ and TP is expected since higher BD values imply in lower TP values and vice versa, as found by Wendling et al. (2012), in a "Latossolo VermelhoAmarelo distrófico" (Oxisol) under no-tillage system. Pacheco \& Cantalice (2010) state that the PR values become higher as decreasing soil moisture (U). This happens because water 
acts in two ways on the PR and to the studied: it decreases the cohesion between the solid particles, and forms water films over the soil particles, reducing the friction between them. Studying an "Argissolo-Amarelo" (Ultisol) in the Coastal Plains of Alagoas state, Magalhães et al. (2009) reported that the dynamics of PR and BD, when determined in soil under machine traffic in sugarcane harvesting, is higher when compared to soil under pasture, as well as there is a reduction in total porosity (TP).

Torres et al. (2012) in a "Latossolo Vermelho distrófico" (Oxisol) with $770 \mathrm{~g} \mathrm{~kg}^{-1}$ of sand content, under non-irrigated pasture, found positive correlations between bulk density and soil moisture. Negative correlations between PR
(4.46 MPa) and DS $\left(1.48 \mathrm{~kg} \mathrm{dm}^{-3}\right)$ and $U(11 \%)$ in the topsoil $(0-0.10 \mathrm{~m})$ were observed.

The negative correlation between $\mathrm{BD}_{2}$ and $\mathrm{URP}_{2}$ at the planting row (BD ranging from 1.30 to $1.60 \mathrm{~kg} \mathrm{dm}^{-3}$ ) indicates that lower soil moisture leads to higher bulk density and vice versa. Intrinsic characteristics of the soil, such as cohesive character, led to increasing the PRRow 2 as increase soil moisture in the layer of 0,20-0,40 $\mathrm{m}$ depth. However, it is observed that the soil moisture showed low values ranging from 3 to $13 \%$.

The parameters of the semivariograms standardized by the data variance fitted to the soil physical attributes at the layer of 0-0.20 m and 0.20-0.40 m were shown in Table 2.

Table 2. Parameters and models of the standardized semivariograms of the soil physical attributes.

\begin{tabular}{|c|c|c|c|c|c|c|c|}
\hline Attributes & model & $C_{0}$ & $\mathrm{C}_{0}+\mathrm{C}$ & $a(m)$ & $\mathrm{R}^{2}(\%)$ & SDD (\%) & $\mathrm{r}-\mathrm{CV}$ \\
\hline $\mathrm{BD}_{1}\left(\mathrm{~kg} \mathrm{dm}^{-3}\right)$ & EXP & 0,10 & 0,96 & 20 & 93 & 13 & 0,46 \\
\hline $\mathrm{BD}_{2}\left(\mathrm{~kg} \mathrm{dm}^{-3}\right)$ & SPH & 0,14 & 0,90 & 28 & 96 & 11 & 0,58 \\
\hline PRPR , $(\mathrm{MPa})$ & EXP & 0,06 & 0,95 & 20 & 71 & 3,0 & 0,48 \\
\hline $\mathrm{PRPR}_{2}(\mathrm{MPa})$ & EXP & 0,26 & 1.00 & 20 & 83 & 25 & 0,40 \\
\hline $\mathrm{UPR}_{1}(\%)$ & EXP & 0,01 & 0,97 & 20 & 93 & 10 & 0,34 \\
\hline$U \operatorname{UPR}_{2}(\%)$ & PNE & - & - & - & - & - & - \\
\hline PRROW $_{1}(\mathrm{MPa})$ & EXP & 0,25 & 0,90 & 18 & 80 & 28 & 0,40 \\
\hline PRROW $_{2}(\mathrm{MPa})$ & EXP & 0,11 & 1,05 & 20 & 78 & 10 & 0,38 \\
\hline URow $_{1}(\%)$ & EXP & 0,05 & 0,99 & 20 & 70 & 4,0 & 0,40 \\
\hline UROW $_{2}(\%)$ & PNE & - & - & - & - & - & - \\
\hline$T_{1}\left(m^{3} m^{-3}\right)$ & EXP & 0,41 & 1,07 & 20 & 72 & 40 & 0,39 \\
\hline $\mathrm{TP}_{2}\left(\mathrm{~m}^{3} \mathrm{~m}^{-3}\right)$ & PNE & - & - & - & - & - & - \\
\hline
\end{tabular}

1: layer of 0-0,20 m depth; 2: layer of 0,20-0,40 m depth; SPH: Spherical model; EXP: Exponential model; PNE: Pure Nugget Effect; r-cv: Coefficient of correlation between measured value and estimated value by the cross-validation. $C_{0}$ : nugget effect; $C_{0}+C$ : sill; a: range of spatial dependence; $R^{2}$ : Coefficient of multiple determination; and SDD: Spatial dependence degree.

The chosen models showed $\mathrm{R}^{2}$ higher than $70.0 \%$, that is, most of the variability in the estimated semivariance values is explained by the models. The correlation between the measured values and estimated values by the cross-validation showed significant correlation coefficients ( $r-c v)(p<0.05)$.

The $U_{P R}, U_{2} U_{12}$ and $\mathrm{TP}_{2}$ attributes showed a pure nugget effect (PNE), which indicates non-spatial dependence, that is, the samples are independent for distances greater than the lowest sample grid distance $(5.7 \mathrm{~m})$. In these cases, the data show a random distribution and using the mean it is a possible estimate of the attribute and the classic statistic explains the variations in the area.

For the other attributes, the the intrinsic hypothesis, which is a minimum requirement for geostatistical analysis, was met. The spherical model was fitted to $\mathrm{BD}_{2}$ data and the exponential model to the other attributes. These models are the ones that best fit soil attributes.

The nugget effect $\left(C_{0}\right)$ represents unexplained or random variance, often caused by measurement errors or attribute variations that cannot be detected on the sampling scale. The PRRow, and $\mathrm{TP}_{1}$ at the layer of 0-0.20 m depth showed the highest $C_{0}$ values, whereas the lowest ones were for the PRPR and PRPR . $_{1}$

$\mathrm{C}_{0}$ is important for Kriging interpolation since the lower its value the greater the continuity of the phenomenon and the smaller the variance of the estimate. The lower the proportion of $\mathrm{C}_{0}$ in relation to the semivariogram 
sill, the greater the spatial dependence of the attribute (Cambardella et al. 1994). The spatial dependence degree (SDD) was strong for all attributes (SDD $\leq 25.0 \%$ ), except for PRROWl and TP1, which showed moderate spatial dependence $(25 \%<$ SDD $\leq 75.0 \%)$. This fact indicates the spatial relationships existing between the values measured in the study area, showing the contribution of the spatial variance in the total data variance. The presence of spatial dependence in a soil is related to the intrinsic characteristics (texture and mineralogy) and extrinsic (adopted agricultural management).

The semivariograms standardized by the data variance are shown in Figures 2, 3, and 4.

It was observed (Figure 2) the fitting of the experimental semivariograms for the soil physical attributes at the layer of 0-0.20 m depth in the papaya planting row. The exponential fitted model showed the same distribution pattern indicating spatial correlation with

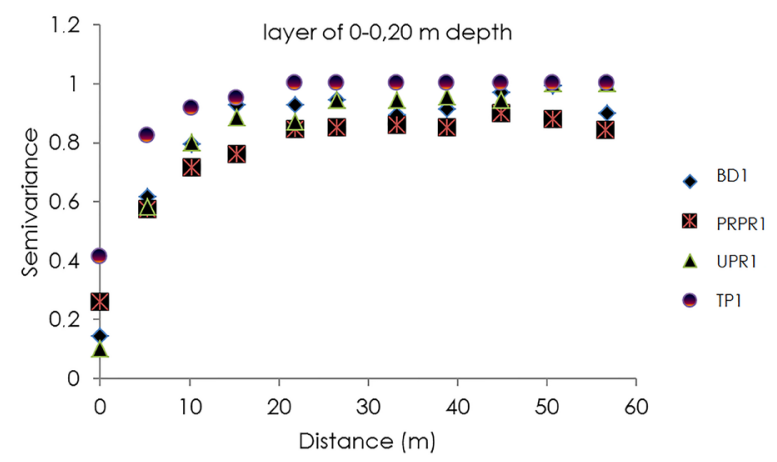

Figure 2. Standardized semivariograms of soil physical attributes at the layer of 0-0.20 $\mathrm{m}$ depth in the planting row. spatial dependence ranges of $20 \mathrm{~m}$. The tillage adopted in the area, at $0.20 \mathrm{~m}$ depth, provided homogenization of the soil physical attributes until the moment of the sexing of the papaya.

In Figure 3, at the layer of $0.20-0.40$ $\mathrm{m}$ depth, the UPR ${ }_{2}$ and $\mathrm{TP}_{2}$ showed no spatial dependence for the sampling grid constructed with the shortest distance between the sampling points $(5.7 \mathrm{~m})$. The $\mathrm{BD}_{2}$ values fitted to the spherical model showed a range of $28 \mathrm{~m}$ and the RPLP ${ }_{2}$ values fitted to the exponential model showed a range of $20 \mathrm{~m}$.

In Figure 4, non-spatial dependence for URow2 was observed. Spatial correlation between PRRow 12 and URpwl was found, as shown by the distribution of semivariance as a function of the vectors $h$ (sampling distance), with the same model and close ranges. In the machine traffic region (row spacing), the effect of wheel pressure on soil propagates similarly at the two soil layers studied.

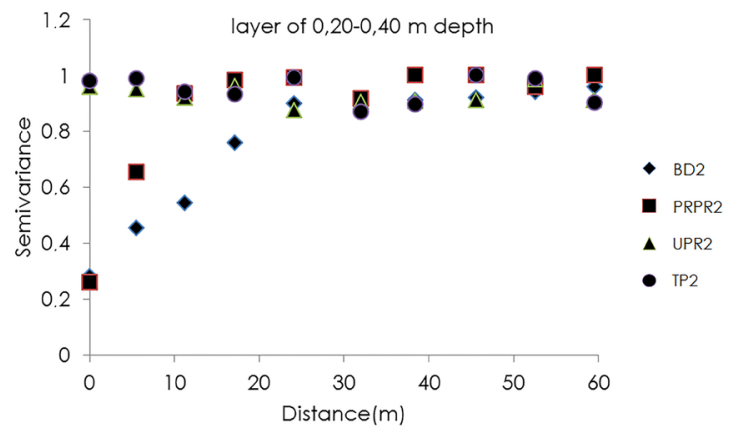

Figure 3. Standardized semivariograms of soil physical attributes at the layer of $0.20-0.40 \mathrm{~m}$ depth in the planting row.

UPR: $(0-0.20 \mathrm{~m})$

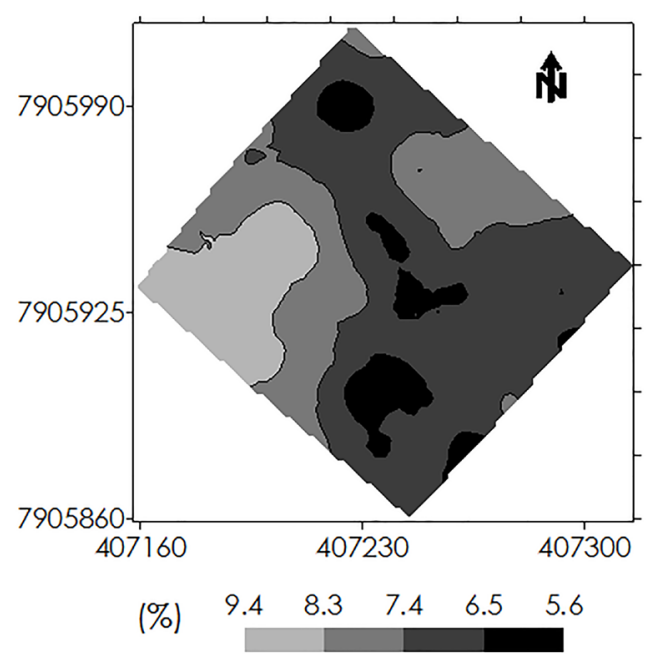

Figure 4. Standardized semivariograms of soil physical attributes at the machine traffic region (row spacing). 
From the fitted semivariograms models, the interpolation was performed by the Ordinary Kriging method to determine values at nonsampled sites and the construction of thematic maps (Figures 5, 6, and 7).

An inversely proportional spatial

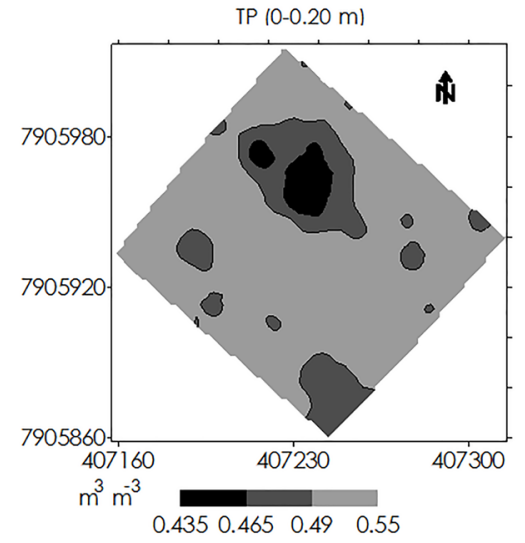

distribution between $\mathrm{BD}_{1}$ and $\mathrm{TP}_{1}$ at the layer of 0-0.20 m depth (Figure 5) was found, confirmed by the $r$ value (-71\%). Lima et al. (2009) verified that TP and BD values showed the same spatial distribution pattern in an "Argissolo Amarelo" (Ultisol) under pasture.

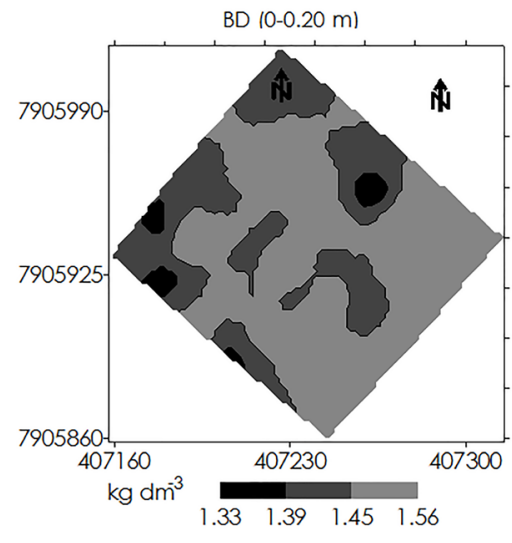

Figure 5. Spatial distribution maps of soil physical attributes at the layer of 0-0.20 m depth: $\mathrm{TP}_{1}$ $\left(\mathrm{m}^{3} \mathrm{~m}^{-3}\right)$ and $B D_{1}\left(\mathrm{~kg} \mathrm{dm}^{-3}\right)$.
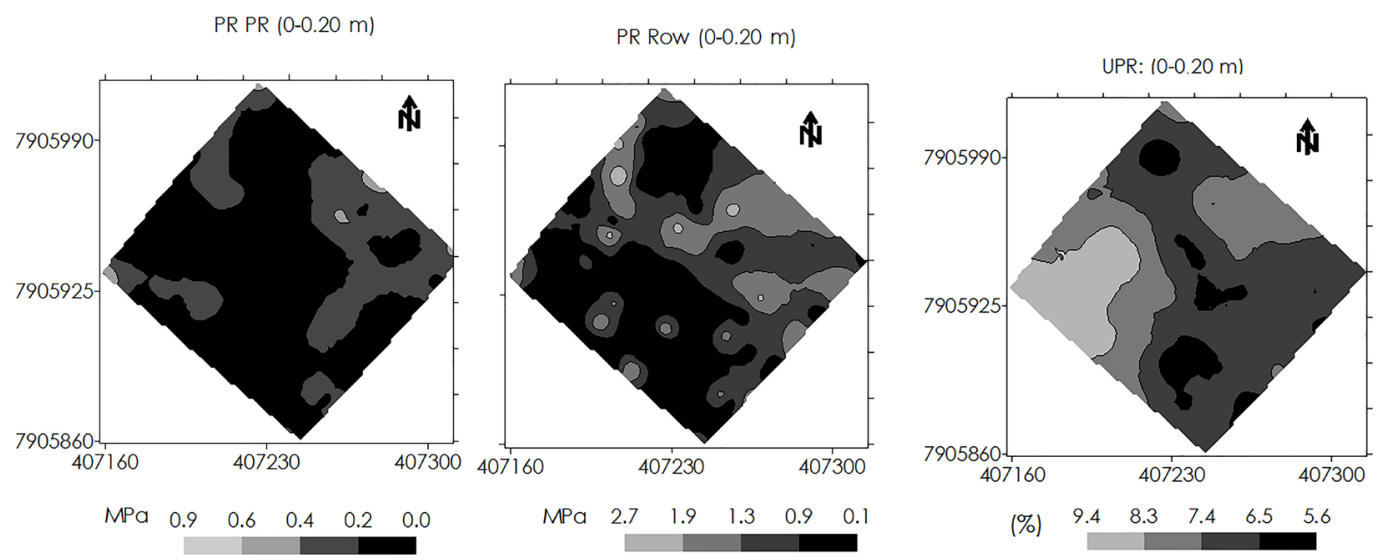

Figure 6. Spatial distribution maps of soil physical attributes at the layer of 0-0.20 m depth: PRPR, PRROW $_{1}\left(M^{\prime} P_{1}\right)$ and UPR
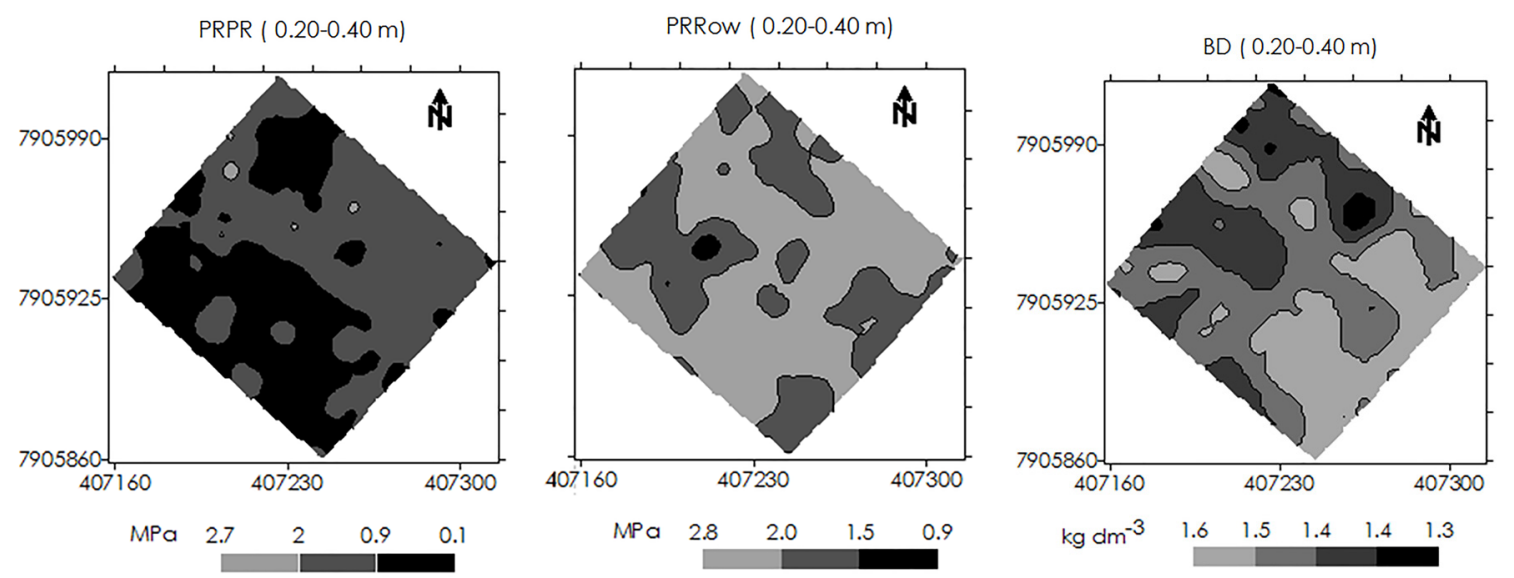

Figure 7. Spatial distribution maps of soil physical attributes at the layer of 0.20-0.40 m depth: $\mathrm{BD}_{2}\left(\mathrm{~kg} \mathrm{dm}^{-3}\right)$; e PRPR $\mathrm{e}_{2} \mathrm{PRROW}{ }_{2}(\mathrm{MPa})$. 
The maps of the attributes PRPR 1, PRRow 1 and UPR 1 are shown in Figure 6. The highest UPR 1 values, to the left of the map, coincide with the lowest PRPR 1 values, demonstrating the effect of reducing the soil hardness provided by the water properties, as verified by Almeida et al. 2008 and Benedetti et al. (2010). Iore et al. (2012) state that the increase of the soil moisture decreases the cohesive forces between the soil particles and the internal friction, causing, then, the decrease in soil penetration resistance.

It was observed in the planting row of the papaya at the layer of $0-0.20 \mathrm{~m}$ depth that $P R$ ranged from 0 to $0.9 \mathrm{MPa}$ (Figure 6), being classified as low compaction, according to Arshad et al. (1996). On the other hand, in the machine traffic row (row spacing), the PR values varies from 0.1 to $0.9 \mathrm{MPa}$ (black color), approximately, in the middle of the area, while the other half showed values greater than $0.9 \mathrm{MPa}$, and the soil compaction classification varied from moderate to high, according to Arshad et al. (1996). In the two maps, the greatest PRPR values are located on the right side. The machines traffic in the row spacing caused a considerable increase of this attribute in the same region as shown in the PRRow map, in light gray color, that is, regions with a tendency to greater compaction. This result is related to the intrinsic soil characteristics such as mineralogy and texture.

Silva et al. (1994) proposed the value of 2.0 MPa as a critical limit for the root growth of the main crops, which in this case, both in the planting row and in the row spacing the values found for PRs, did not compromise the development of the root system until the time of plant sexing.

In the subsurface layer $(0.20-0.40 \mathrm{~m})$ (Figure 7) the $\mathrm{BD}_{2}$ map shows a large part of the area with values greater than $1.4 \mathrm{~kg} \mathrm{dm}^{-3}$ and the $\mathrm{PRPR}_{2}$ with values lower than $2.0 \mathrm{MPa}$, reinforcing the linear correlation $(-0.30)$ found.

Melo Filho et al. (2006) found BD values varying from 1.44 to $1.73 \mathrm{~kg} \mathrm{dm}^{-3}$ in the profile of a cohesive "Latossolo Amarelo" (Oxisol) at a depth greater than $0.40 \mathrm{~m}$, with increasing values in layers rich in sand content and that, consequently, higher PR values.

The PRRow ${ }_{2}$ values increased in relation to $\mathrm{PRPR}_{2}$, showing variation between 2.0 and 2.8
MPa in most of the area (light gray), classified as high by the criteria defined by Arshad et al. (1996).

The difference in PR values between the planting row and the machine traffic regions is justified by the subsoiling only in the planting row (PR) and the occurrence of traffic in the row spacing.

\section{Conclusions}

The management and the cohesive character of the soil influenced the values found for the attributes studied at the layers of $0-0.20$ and $0.20-0.40 \mathrm{~m}$ depth.

The mechanical soil tillage adopted in the area and the traffic of machines used in the papaya management provided soil penetration resistance values five times greater in the row planting at the layer of 0,20-0,40 m depth than at the layer of $0-0.20 \mathrm{~m}$ depth.

The soil penetration resistance in the traffic of machines region (row spacing) showed an increase of 7.5 times greater than the value obtained in the planting row at the layer of $0-0,20$ m depth.

The soil bulk density at the two layers showed the same pattern of spatial distribution, with the same model and similar ranges; and the soil moisture at the layer of 0-0.20 m depth showed great spatial continuity.

\section{Acknowledgments}

To CNPq (National Council of Scientific Researches) for providing a research productivity scholarship to the first author and for paying the publication fees.

\section{References}

Almeida, C.X., Centurion, J.F., Freddi, O.S., Jorge, R.F.; Barbosa, J.C. 2008. Funções de pedotransferência para a curva de resistência à penetração. Revista Brasileira de Ciência do Solo 32:2235-2243.

Andrade, R.S., Stone, L.F., Godoy, S.G. 2013. Estimativa da resistência do solo à penetração baseada no índice $S$ e no estresse efetivo. Revista Brasileira de Engenharia Agrícola e Ambiental 17:932-937.

Arshad, M.A., Lowery, B., Grossman, B. 1996. Physical tests for monitoring soil quality. In: Doran, J.W.; Jones, A.J. (Eds.). Methods for assessing soil 
quality. Madison: Soil Science Society of America, p. 123-141.

Benedetti, M.M., Duartel, I.N., Melo Júnior, H.B., Borges, E.N. 2010. Resistência do solo à penetração em um Latossolo Vermelho distrófico típico sob diferentes usos. Enciclopédia Biosfera $6: 1-9$.

Cambardella C.A., Moorman, T.B., Parkin, T.B., Karlen, D.L., Novak J.M., Turco R.F., Konopka, A.E. 1994. Field-scale variability of soil properties in Central lowa soils. Soil Science Society America Journa 58:1501-1511.

Campos, M.C.C., Oliveira, I.A., Santos, L.A.C. Aquino, R.E., Soares, M.R.D. 2012. Variabilidade espacial da resistência do solo à penetração e umidade em áreas cultivadas com mandioca na região de Humaitá, AM. Revista Agro@mbiente 6:09-16.

Dalchiavon, F.C., Carvalho, M. P., Nogueira, D.C., Romano, D., Abrantes, F.L., Assis, J.T., Oliveira, M.S. 2011 . Pesquisa Agropecuária Tropical 41:8-19.

Embrapa - Empresa Brasileira de Pesquisa Agropecuária. Centro Nacional de Pesquisa dos Solos. Manual de métodos de análise de solo. 2nd ed. Rio de Janeiro: EMBRAPA CNPS, 2011.

Gomes, N.M., Faria, M.A.F., Silva, A. M., Mello, C. R., Marcelo R. Viola, M. R. 2007. Variabilidade espacial de atributos físicos do solo associados ao uso e ocupação da paisagem. Revista Brasileira de Engenharia Agrícola e Ambiental 11: 427-435.

Isaaks, E. H., Srivastava, R. M. 1989. Applied geostatistics: introduction to applied geostatistics. Oxford: University Press. 561p.

Iori, P., Dias Júnior, M.S., Silva, R. B. 2012. Resistência do solo à penetração e ao cisalhamento em diversos usos do solo em áreas de preservação permanente. Bioscience Journal 28:185-195.

Kitamura, A.E., Carvalho, M.P., Lima, C.G.R. 2007. Relação entre a variabilidade espacial das frações granulométricas do solo e a produtividade do feijoeiro sob plantio direto. Revista Brasileira de Ciência do Solo 31:361-369.

Lima, H.V., Silva, A.P., Romero, R.E., Jacomine, P.K.T. 2005. Comportamento físico de um Argissolo Acizentado coeso no estado do Ceará. Revista Brasileira de Ciência do Solo 29:33-40.

Lima, J.S.S., Oliveira, R.B., Quartezani, W.Z. 2007. Variabilidade de atributos físicos de um Latossolo Vermelho-Amarelo sob cultivo de pimenta-doreino. Revista Engenharia na Agricultura 15:290298.

Lima, J.S.S., Oliveira, P.C., Oliveira, R.B., Xavier,
A.C. 2008. Métodos geoestatísticos no estudo da resistência do solo à penetração em trilha de tráfego de tratores na colheita de madeira. Revista Árvore 32:931-938.

Lima, J.S.S., Souza, G.S., Silva, S.A. 2010. Amostragem e variabilidade espacial de atributos químicos do solo em área de vegetação natural em regeneração. Revista Árvore 34:127-136.

Lima, J.S.S., Sattler, M.A., Passos, R.R., Oliveira, ॥ P.C., Souza, G.S. 2009. Variabilidade espacial de atributos físicos de um Argissolo VermelhoAmarelo sob pastagem e vegetação secundária em regeneração natural. Engenharia Agrícola 29:185-195.

Lima, J.S.S., Sturião, W.P., Oliveira, F.B., Gontijo, I., Souza, C.G. 2012. Agricultura de precisão no cultivo do mamoeiro: um potencial. In: Pratissoli, D., Jesus Junior, W.C., Zago, H.B., Alves, F.R., Viana, U.R. Santos Junior, H.J.G. (Eds). Tópicos especiais em Produção Vegetal III. CCA-UFES, Alegre-ES. p. 810-837.

Magalhães, W.A., Cremon, C., Mapeli, N.C.M., Silva, W.M., Carvalho, J.M.C., Mota, M. S. 2009. Determinação da resistência do solo a penetração sob diferentes sistemas de cultivo em um Latossolo sob Bioma Pantanal. Agrarian 2:21-32.

Melo Filho, J.F., Oliveira, A.S., Lopes, L.C., Vellame, L.M. 2006. Análise estatística exploratória e variabilidade da densidade do solo em um perfil de Latossolo Amarelo coeso dos tabuleiros costeiros da Bahia. Ciência e Agrotecnologia 30:199-205.

Ortiz, J.L., Vettorazzi, C.A., Couto, H.T.Z., Gonçalves, J.L.M. 2006. Relações espaciais entre o potencial produtivo de um povoamento de eucalipto e atributos do solo e do relevo. Scientia Forestalis 72:67-79.

Pires, L.F., Rosa, J.A., Timm, L.C. 2011 . Comparação de métodos de medida da densidade do solo. Acta Scientiarum Agronomy 33:161-170.

Pacheco, E. P., Cantalice, J. R. B. 2011. Compressibilidade, resistência à penetração e intervalo hídrico ótimo de um Argissolo-Amarelo cultivado com cana-de-açúcar nos tabuleiros costeiros de Alagoas. Revista Brasileira de Ciência do Solo. 35: 403-415.

Silva, A.P., Kay, B.D., Perfect, E. 1994. Characterization of the least limiting water range of soils. Soil Science Society America Journal 58:1775-1781.

Silveira, D.C., Melo Filho, J. F., Sacramento, J. A. A., Silveira, E. C. P. 2010. Relação umidade versus resistência à penetração para um Argissolo amarelo distrocoeso no recôncavo da Bahia. 
Revista Brasileira de Ciência do solo 34: 659-667.

Souza, Z.M., Marques Júnior, J., Pereira, G.T. 2009.

Geoestatística e atributos do solo em áreas cultivadas com cana-de-açúcar. Ciência Rural 40:48-56.

Timm, L.C., Pires. L,F., Roveratti, R., Arthur, R.C.J., Reichardt, K., Oliveira, J.C.M., Bacchi, O.O.S 2006. Field spatial and temporal patterns of soil water content and bulk density changes. Scientia Agrícola 63:55-64.

Torres, J.L.R., Rodrigues Junior, D.J., Sene, G.A., Jaime, D.G., Vieira, D.M.S. 2012. Resistência à penetração em área de pastagem de capim tifton, influenciada pelo pisoteio e irrigação. Bioscience Journal 28: 232-239.

Warrick, A.W., Nielsen, D.R. 1980. Spatial variability of soil physical properties in the field. IN.: Hillel, D. (Ed). Applications of soil physics. New York: Academic, p.319-344.

Wendling, B., Vinhal-Freitas, I. C., Oliveira, R. C., Babata, M. M., Borges, E. N. 2012. Densidade, agregação e porosidade do solo em áreas de conversão do cerrado em floresta de pinus, pastagem e plantio direto. Bioscience Journal 28: 256-265. 